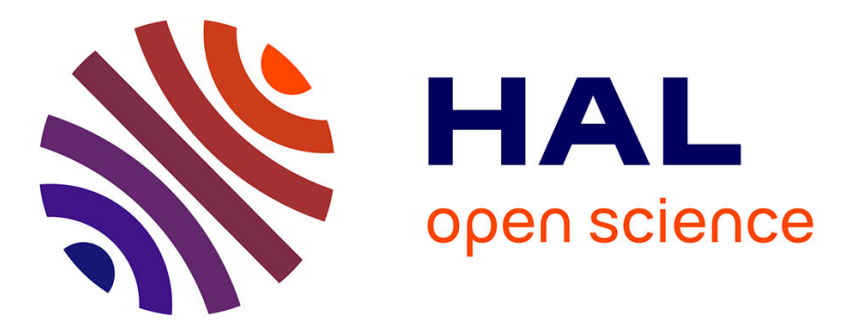

\title{
Secondary Phosphine Oxides as Multitalented Preligands En Route to the Chemoselective Palladium-Catalyzed Oxidation of Alcohols
}

Alexandre Vasseur, Romain Membrat, David Gatineau, Alphonse Tenaglia, Didier Nuel, Laurent Giordano

\section{To cite this version:}

Alexandre Vasseur, Romain Membrat, David Gatineau, Alphonse Tenaglia, Didier Nuel, et al.. Secondary Phosphine Oxides as Multitalented Preligands En Route to the Chemoselective PalladiumCatalyzed Oxidation of Alcohols. ChemCatChem, 2017, 9 (5), pp.728 - 732. 10.1002/cctc.201601261 . hal-01682727

\section{HAL Id: hal-01682727 https://hal.science/hal-01682727}

Submitted on 14 Apr 2018

HAL is a multi-disciplinary open access archive for the deposit and dissemination of scientific research documents, whether they are published or not. The documents may come from teaching and research institutions in France or abroad, or from public or private research centers.
L'archive ouverte pluridisciplinaire HAL, est destinée au dépôt et à la diffusion de documents scientifiques de niveau recherche, publiés ou non, émanant des établissements d'enseignement et de recherche français ou étrangers, des laboratoires publics ou privés. 


\title{
Secondary Phosphine Oxides as Multitalented Preligands En Route to the Chemoselective Palladium-Catalyzed Oxidation of Alcohols
}

\author{
Alexandre Vasseur ${ }^{+}$, Romain Membrat ${ }^{+}$, David Gatineau, Alphonse Tenaglia, Didier Nuel,* \\ and Laurent Giordano*[a]
}

Secondary phosphine oxides $\mathrm{O}=\mathrm{PHR}_{2}$ (SPOs) were identified as multitalented preligands for the chemoselective Pd-catalyzed oxidation of alcohols by a hydrogen-abstracting methodology. SPOs were found to promote the hydrogen-abstraction step as well as hydrogen transfer to a Michael acceptor by generating a putative active $\mathrm{H}-\mathrm{Pd}$ species. The catalytic system operates under neutral conditions and was proven to be compatible with various electrophilic and nucleophilic functionalities within the substrates as well as water- and air-sensitive functional groups.

The surge in transition-metal-based catalysis has unquestionably paved the way for the design of efficient catalytic systems in the field of the oxidation of alcohols, as evidenced by the numerous reports in this regard. ${ }^{[1]}$ In particular, the recent reemerging interest in using palladium(II)-based catalyst ${ }^{[2]}$ in combination with oxygen ${ }^{[3]}$ has conditioned the design of well-defined complexes for achieving highly selective transformations of primary or secondary alcohols into the corresponding aldehydes or ketones, respectively. ${ }^{[4]}$ Such a Pd"-based approach typically involves a putative $\mathrm{Pd}$-hydride species as the crossroads through alcoholate formation and subsequent $\beta-\mathrm{H}$ elimination. Completion of the catalytic cycle then requires either reoxidation of a $\mathrm{Pd}^{0}$ species or direct reaction of $\mathrm{HPdX}$ with oxygen to regenerate the active catalyst (Scheme 1, pathway a). ${ }^{[5]}$ Despite the clear environmental benefit of using oxygen and great advances achieved thereof, many serious issues such as intolerance of sensitive functional groups and the nature of the ligands may emerge in maintaining catalytic activity and/or regio- and chemoselectivity. ${ }^{[6]}$ Alternatively, oxidizing alcohols in the absence of any formal reoxidant necessarily implies metal-mediated hydrogen transfers from the substrate to a hydrogen acceptor such as electron-poor alkenes. ${ }^{[7]}$ This approach was recently termed "abstracting-hydrogen methodology"[8] (AHM) (Scheme 1, pathway b). Surprisingly, scarce literature precedent ${ }^{[9]}$ in which this combination has

\footnotetext{
[a] Dr. A. Vasseur, ${ }^{+}$R. Membrat, ${ }^{+}$Dr. D. Gatineau, Dr. A. Tenaglia, Dr. D. Nuel, Dr. L. Giordano

Aix-Marseille Univ, CNRS, Centrale Marseille, iSm2, Marseille (France)

E-mail: didier.nuel@centrale-marseille.fr laurent.giordano@centrale-marseille.fr

$\left.{ }^{[+}\right]$These authors contributed equally to this work.
}

convincingly been used proves that such a synergism remains to be harnessed. It should be noted that oxidation through hydrogen transfer is well documented within ruthenium chemistry. ${ }^{[7]}$ However, most of the involved substrates are devoid of other functional groups, ${ }^{[10]}$ probably owing to the high oxophilicity of the metal and the basic conditions, which are usually required.

The AHM-based approach is feasible if the $\mathrm{H}-\mathrm{Pd}^{\prime \prime}$ species generated by alcohol oxidation reacts with the $\mathrm{H}$-acceptor faster than it suffers from reductive elimination or a degradation process, and the quest for a multitalented preligand $L$ is therefore of paramount importance. First, $\mathbf{L}$ should sufficiently provide electron density towards the metal but still maintain moderate steric hindrance. ${ }^{[11]}$ Second, it should not promote intramolecular deprotonation of the $\mathrm{Pd}-\mathrm{H}$ bond, which thus rules out a good number of bidentate nitrogen ligands. ${ }^{[12]}$ Third, it should operate under neutral conditions to preserve the chemical integrity of both the $\mathrm{Pd}-\mathrm{H}$ species and the substrate. Lastly, L would be synthetically useful only if it is both air and moisture stable and easy to handle. ${ }^{[13]}$ In this context, finding an alternative to ligands that are able to stabilize $\mathrm{H}-\mathrm{Pd}$ species such as pincer ligands is highly desirable.

Our solution to tackle this vexing issue lies in secondary phosphine oxides ${ }^{[14]}$ (SPOs, Scheme 2), which are air stable, ${ }^{[15]}$ unaffected by water, ${ }^{[16]}$ easy to handle, ${ }^{[14 a]}$ and good electrondonating preligands. ${ }^{[17]}$ For instance, complex A, easily available from SPOs and $\mathrm{Pd}(\mathrm{OAc})_{2}{ }^{[18]}$ would be expected to generate a $\mathrm{H}-\mathrm{Pd}$ species $\mathbf{B}$ through oxidation of an alcohol.

Moreover, the six-membered hydrogen-bonded chelate structure of B would enable stabilization of a 14-electron cationic Pd" complex, from which reductive elimination would be rather difficult. This peculiar structure would also allow strong minimization of the steric hindrance, as the edge between the $\mathrm{P}$ atom and the hydride could approach $120^{\circ}$. $^{[19]}$

In earlier studies, we noticed that treatment of $\mathrm{Pd}(\mathrm{dba})_{2}$ ( $\mathrm{dba}=$ dibenzylideneacetone) with rac-tert-butyl(phenyl)phosphane oxide ( $\mathbf{L}, 2$ equiv.) and acetic acid (2 equiv.) in toluene resulted in the reduction of one $\mathrm{C}=\mathrm{C}$ bond of the dba ligand (Scheme 3$)^{[20]}$ This result could be attributed to putative species $\mathbf{C}$ formed through ligand exchange. The loss of acetic acid would afford Pd"-hydride complex C, which upon loss of $\mathrm{AcOH}$ yields $\mathbf{D}$. The latter then reacts with $\mathrm{dba}$ and $\mathrm{AcOH}$ to deliver $\mathbf{E}$. This observation clearly highlights $\mathrm{L}$ as a $\mathrm{Pd}^{\prime \prime}-\mathrm{H}$ generator preligand class, all the more so given that oxidative addition of $\mathrm{AcOH}$ to $\mathrm{Pd}^{0}$ is known to proceed through an unfavorable equilibrium. ${ }^{[21]}$ 


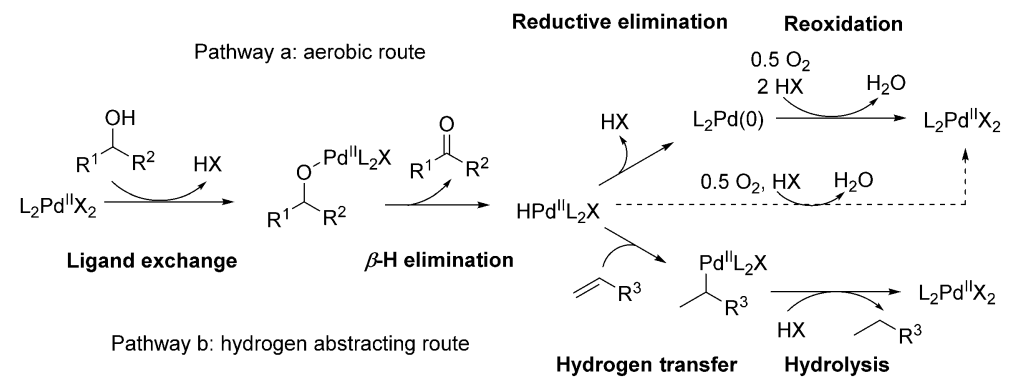

Scheme 1. Catalytic pathways for the Pd"-catalyzed oxidation of alcohols.

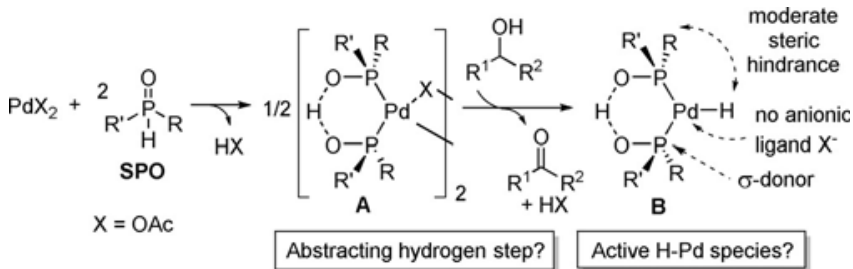

Scheme 2. Proposed ligand-specific strategy to generate a $\mathrm{H}-\mathrm{Pd}$ species.

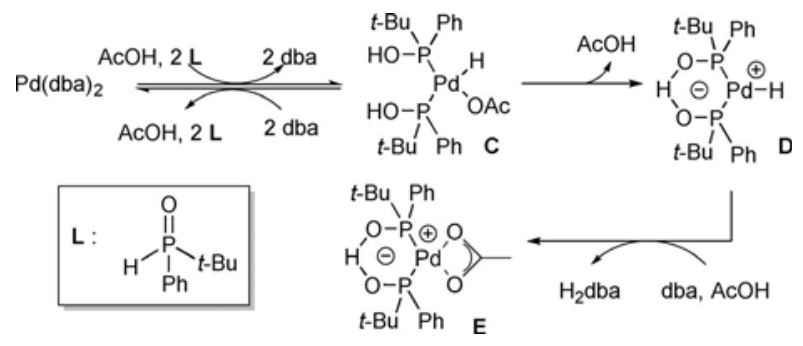

Scheme 3. Proposed mechanism for the double-bond reduction of dba ( $\mathrm{dba}=$ dibenzylideneacetone; $\mathrm{H}_{2} \mathrm{dba}=1,5$-diphenyl-pent-1-en-3-one).

These observations led us to investigate the formation of $\mathbf{D}$ from alcohols instead of $\mathrm{AcOH}$ so as to perform their oxidation through AHM. The oxidation of benzyl alcohol ( $3 \mathrm{a}$ ) was first studied in toluene at $90-105^{\circ} \mathrm{C}$ over $12 \mathrm{~h}$ in the presence of easily prepared well-defined complex $\mathbf{1}$ as the catalyst, ${ }^{[18 c]}$ a series of hydrogen acceptors $\mathbf{2}$, and in the presence or absence of water as a co-solvent (Table 1). Whereas no reaction occurred in the absence of hydrogen acceptor 2 and co-solvent, low yields were obtained when the reaction was performed with $2 \mathrm{a}$ and 1 (Table 1, entries 1 and 2). Though yields were similar to those obtained with SPO, the use of $\mathrm{PPh}_{3}$ as the ligand led to the formation of Pd black, presumably as a result of the instability of the generated HPdOAc species or direct $\mathrm{PPh}_{3}$-assisted reduction of $\mathrm{Pd}(\mathrm{OAc})_{2}{ }^{[22]}$ (Table 1 , entry 3 ). Surprisingly, adding water as a co-solvent slightly improved the yield (Table 1, entry 4), and increasing the temperature to $105^{\circ} \mathrm{C}$ provided $4 \mathrm{a}$ in $58 \%$ yield (Table 1 , entry 5 ). Whereas replacing $\mathbf{2}$ a by $\mathbf{2} \mathbf{b}, \mathbf{2} \mathbf{c}$, or $\mathbf{2} \mathbf{d}$ dramatically decreased the yield or did not impact the efficiency of the transformation (Table 1 , entries 6-8), we were pleased to find that the use of $2 \mathrm{e}$ allowed the formation of $\mathbf{4} \mathbf{a}$ in $88 \%$ yield. In contrast, $\mathbf{3}$ a failed

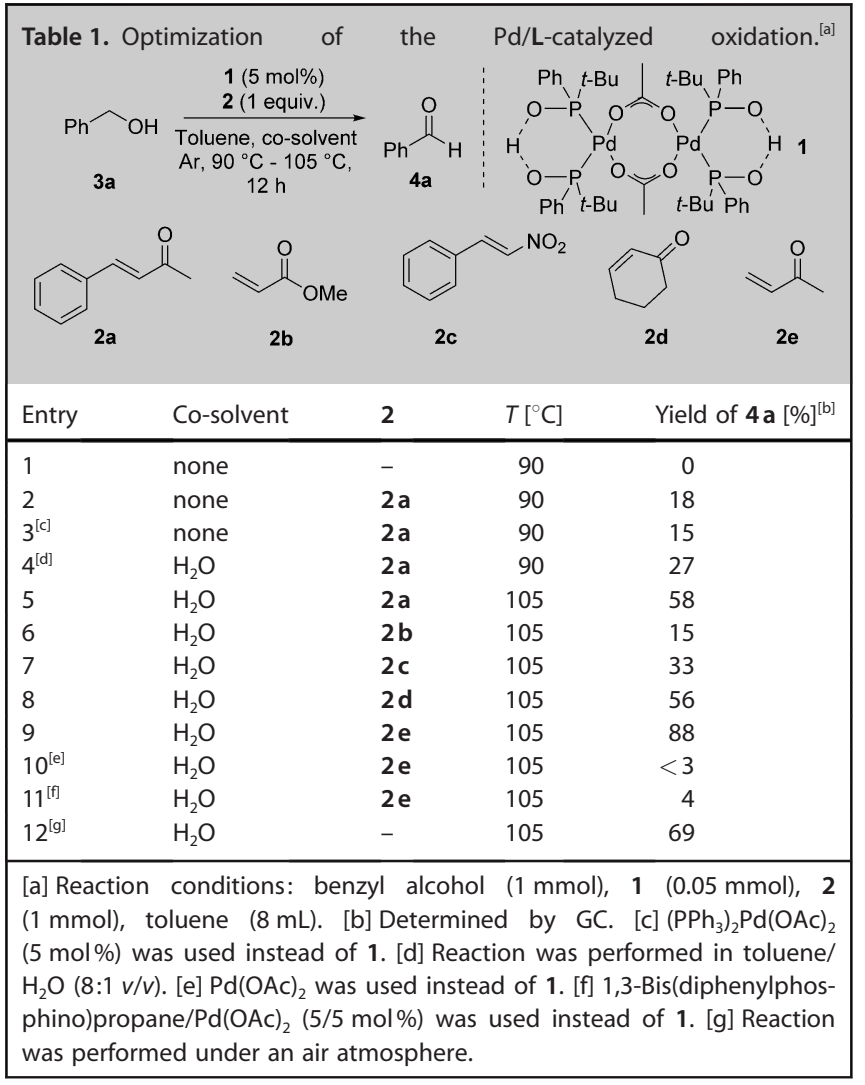

to react under similar conditions if $\operatorname{Pd}(\mathrm{OAc})_{2}$ was used instead of 1 in the absence of a ligand (Table 1, entry 10). Using bis(diphenylphosphino)propane as the ligand, which mimics the SPO-chelate structure, in the presence of $\mathrm{Pd}(\mathrm{OAc})_{2}$ afforded $4 \mathrm{a}$ in only $4 \%$ yield and conversion of $\mathrm{H}-\mathrm{Pd}$ into $\mathrm{Pd}^{0} .{ }^{[23]}$ This highlights the role of SPOs in stabilizing palladium intermediates (Table 1, entry 11). Lastly, 4 a could also be obtained in $69 \%$ yield by using air as a reoxidant, stressing the robustness of 1 (Table 1, entry 12).

The scope of the process was then examined (Table 2). Thus, a wide range of secondary benzylic alcohols were successfully oxidized into corresponding ketones $\mathbf{3} \mathbf{b}-\mathbf{h}$. Aliphatic cyclic alcohols $\mathbf{3} \mathbf{i}-\mathbf{n}$ and acyclic secondary alcohols $\mathbf{3 0 - \mathbf { s }}$ including sterically congested ones were also converted into their corresponding ketones in good to excellent yields. Interestingly, the 


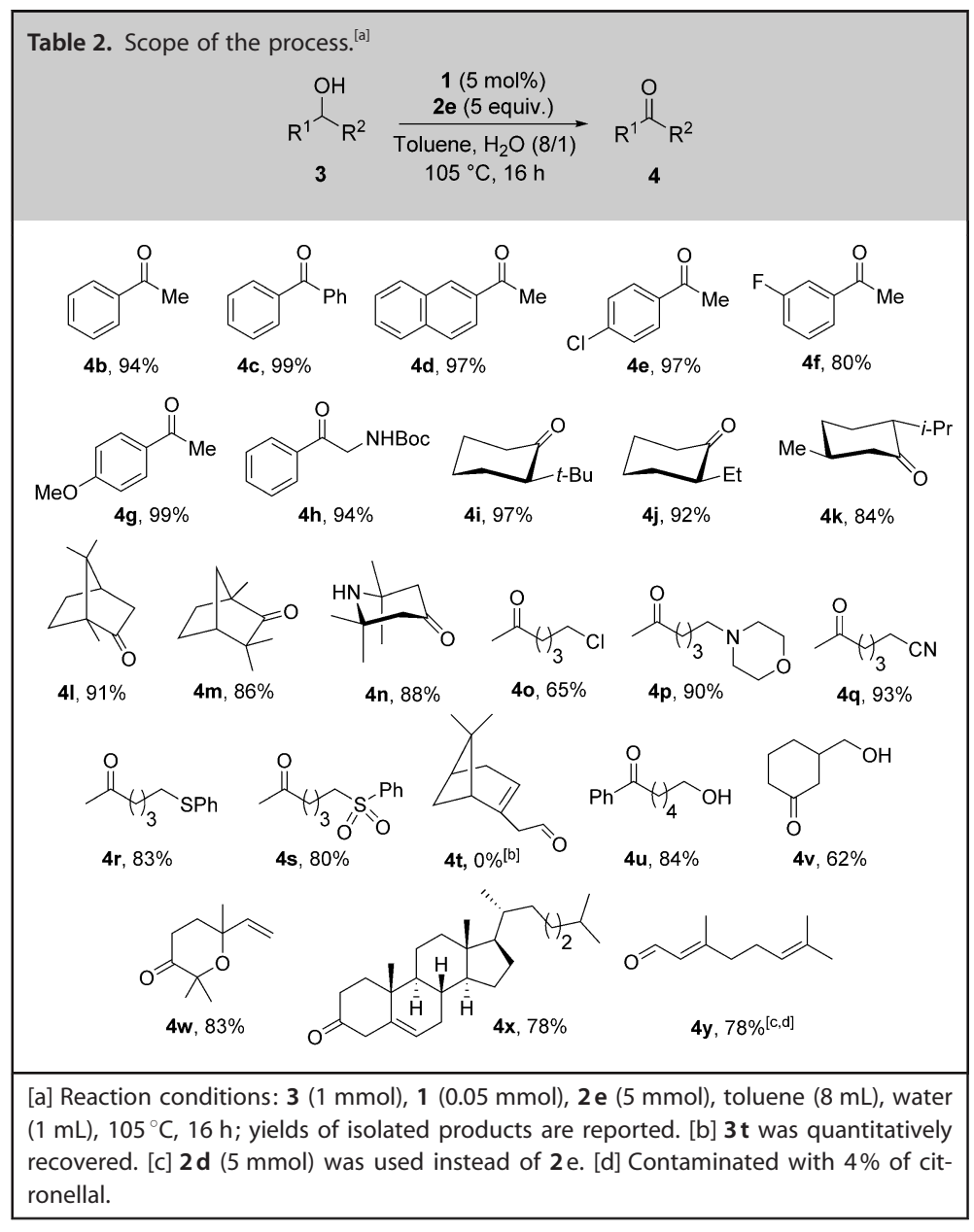

reaction involving $\mathbf{3} \mathbf{q}$ yielded $\mathbf{4} \mathbf{q}$ in $\mathbf{9 3} \%$ yield without hydrolysis of the nitrile group. ${ }^{[24]}$ Whereas the aerobic Pd"-catalyzed oxidation of alcohols in the presence of highly air-sensitive moieties is quite limited, $4 r$ could be obtained in a very good yield from $3 r$ without any alteration of the phenylthio group. It should be stressed that despite well-known ligand properties, phenylthio group-, amine-, and nitrile-containing substrates did not affect the structure of the catalyst, which highlighted the robustness of the $\left[(\mathbf{L})(\mathbf{L}-\mathbf{H}) \mathrm{Pd}^{\prime \prime}\right]$ species. Furthermore, both $\mathbf{3 r}$ and $\mathbf{3} \mathbf{s}$ have been identified as notoriously difficult substrate classes in Pd-catalyzed oxidation reactions. ${ }^{[25]}$ For this catalytic system operating under neutral conditions, basesensitive sulfonyl groups ${ }^{[26]}$ remained intact, as in $4 \mathrm{~s}$, whereas they were previously established to undergo elimination under Ru-catalyzed hydrogen-transfer reaction conditions. ${ }^{[27]} \mathrm{Al}-$ though they might lead to undesired products owing to their potential $\mathrm{H}$-acceptor properties, good yields were obtained for $4 w, 4 x$, and $4 y$ from $3 w, 3 x$, and $3 y$, respectively, for which the integrity of the double bonds was preserved. Changing $2 \mathrm{e}$ by $\mathbf{2} \mathbf{d}$ was, however, essential for the reaction involving $\mathbf{3} \mathbf{y}$ to minimize over-reduction of the conjugated double bond. As primary aliphatic alcohol substrate $\mathbf{3} \mathbf{t}$ was found to be reluctant to react, we examined the possibility to achieve chemoselective oxidation of diols featuring both primary and secondary alcohol functions. We were delighted to find that the method was highly selective towards secondary alcohols, as illustrated by the obtainment of $4 \mathbf{u}$ and $\mathbf{4 v}$. Although not mentioned in Table 2, it should be pointed out that $\mathbf{4 b}, \mathbf{4 i}, \mathbf{4 k}, \mathbf{4 l}$, and $\mathbf{4 x}$ were also obtained in yields similar to those reported by using water as a unique solvent.

The behavior of 1 in a toluene/ $\mathrm{H}_{2} \mathrm{O}(8: 1)$ mixture at $105^{\circ} \mathrm{C}$ was then studied by using ESI(+)-MS (see the Supporting Information). After $15 \mathrm{~min}$ of stirring, a species at $m / z=999$ was intercepted and identified as the $\left[\left(\mathrm{L}_{2}-2 \mathrm{H}+\mathrm{H}\right) \mathrm{PdOH}\right]^{+}$complex in a dimeric form with $\left[\mathrm{L}_{2} \mathrm{PdOH}\right]^{+}$. This species was also intercepted in the presence of substrates $\mathbf{3} \mathbf{b}$ and $\mathbf{2} \mathbf{a}$ and could rationally originate from dihydroxy-bridged palladium dimer $\mathbf{F}$ (Figure 1). The trimeric $\mathrm{Pd}^{\prime \prime}$ acetate complex is known to be easily converted into $\left[\mathrm{Pd}_{3}\left(\mu^{2}-\right.\right.$ $\left.\mathrm{OH})(\mathrm{OAC})_{5}\right]$ in the presence of water, ${ }^{[28]}$ and a large number of dimeric bidentate diphosphine Pd" complexes were also proven to suffer from similar transformations if dissolved in water. ${ }^{[9 d, 29]}$ Notably, a monomeric analogous species was reported to be active in aerobic Pd"-catalyzed oxidation reactions of alcohols in aqueous media. ${ }^{[9 d, 25]}$

We lastly studied the hydrogen-transfer step (Scheme 4). The reaction involving $d_{1}-\mathbf{3} \mathbf{b}$ as the deuterium source and $\mathbf{2} \mathrm{a}$ as the $\mathrm{H}$-acceptor afforded corresponding oxidized product $\mathbf{4} \mathbf{b}$ and monodeuterated product $d_{1}-2 \mathrm{a}$, in which deuterium was exclusively placed at $C 4$, highlighting a highly regioselective $D$ transfer (Scheme 4a). The partial deuterium incorporation can be rationalized by possible $\mathrm{D} / \mathrm{H}$ exchange

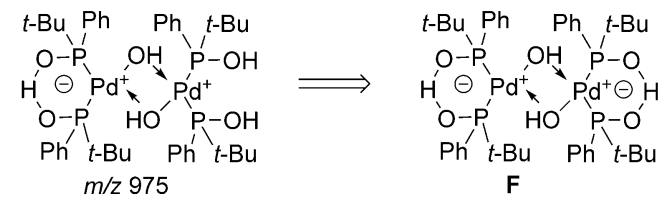

Figure 1. Detected cationic hydroxybispalladium(II) species.

between the formed deuteridopalladium species and the water co-solvent. ${ }^{[30]}$ In contrast, a similar reaction conducted with $\mathbf{3} \mathbf{b}$ in a mixture of toluene/ $\mathrm{D}_{2} \mathrm{O}(8: 1)$ instead of $d_{1}-\mathbf{3} \mathbf{b}$ in a mixture of toluene/ $\mathrm{H}_{2} \mathrm{O}$ led to $d_{2}-2 \mathrm{a}$, in which $100 \%$ deuterium incorporation was observed at C3 (Scheme $4 \mathrm{~b}$ ). This result clearly suggests that once the double bond of $2 \mathrm{a}$ is inserted into the $\mathrm{H}-\mathrm{Pd}$ bond, formed C-bound $\mathrm{Pd}$ " enolate $\mathrm{I}$ is more prone to undergo hydrolytic cleavage than $\beta-\mathrm{H}$ elimination, despite its potentially available coordination site and the absence of an excess amount of anionic $X^{-}$ligand. ${ }^{[31]}$ The reaction performed with $d_{1}-3 \mathbf{b}$ in a toluene/ $\mathrm{D}_{2} \mathrm{O}$ mixture afforded $d_{2}-2$ a with quantitative deuterium incorporation at $\mathrm{C} 3$ and $\mathrm{C} 4$ (Scheme $4 \mathrm{C}$ ). Lastly, heating $\mathrm{H}_{2}-2 \mathrm{a}$ at $105^{\circ} \mathrm{C}$ for $16 \mathrm{~h}$ in a toluene/ $\mathrm{D}_{2} \mathrm{O}$ mixture as the solvent and in the absence of 1 resulted in no D incorporation at C3 (see the Supporting Information). It is apparent that our reaction conditions did not allow 


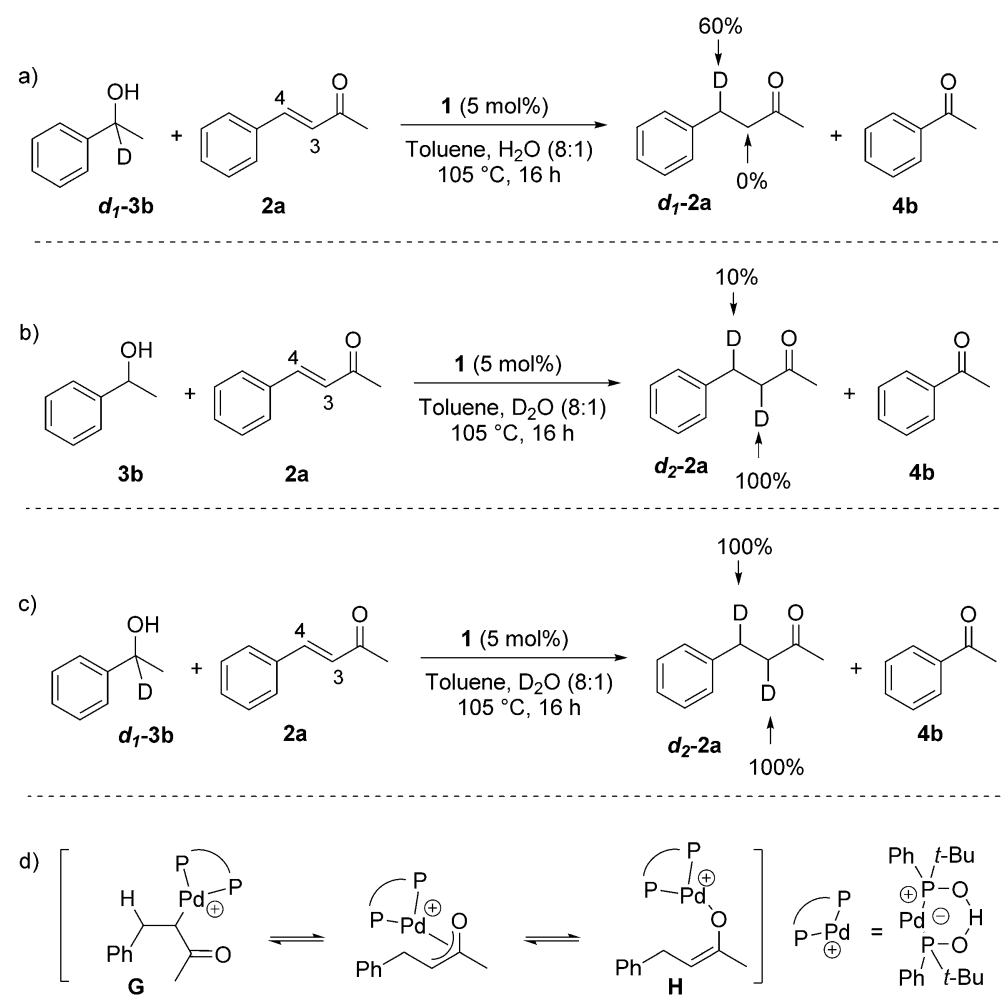

Scheme 4. Deuterium-labeling experiments.

direct $\mathrm{C} \alpha-\mathrm{Pd}$ bond heterolytic cleavage and subsequent protonation of the organic moiety to be envisaged at first sight, as such a chemical event usually requires reduction involving both tertiary amines and formic acid. ${ }^{[32]}$ A plausible alternative to this mechanism would be the presence of an L-promoted equilibrium between $\mathbf{G}$ and species $\mathbf{H}$ via an oxa- $\boldsymbol{\pi}$-allylpalladium; $\mathbf{H}$ is susceptible to heterolytic fission owing to the ionic character of the Pd-O structure (Scheme $4 \mathrm{~d}$ ). ${ }^{[33]}$

In view of the above results, we propose the following mechanism (Scheme 5). Catalyst $\mathbf{1}$ is converted into inactive precatalyst $\mathbf{F}$ in the presence of water, namely, a dihydroxybridged $\mathrm{Pd}$ dimer, which is in equilibrium with active monomer I. The reaction of I with $d_{1}-3$ provides deuteridopalladium species J, 4, and water either through a hydroxy $\mathrm{Pd}^{\prime \prime}$-alcohol ${ }^{[34]}$ or an alkoxypalladium intermediate. ${ }^{[35]}$ Double-bond insertion of $2 \mathrm{e}$ into the $\mathrm{H}-\mathrm{Pd}$ bond then yields $\mathbf{C}$-bound $\mathrm{Pd}^{\text {"l }}$ enolate $\mathbf{M}$ in equilibrium with $\mathbf{N}$, as suggested by deuterium-labeling experiments. Subsequent protolysis of the latter finally restores active catalyst I and delivers deuterohydrogenated compound $d_{1}-2$ e.

In conclusion, we developed a novel method for the Pd"-catalyzed oxidation of alcohols through abstracting-hydrogen methodology by using secondary phosphine oxides (SPOs) as multitalented preligands. Scope and mechanistic investigations showed that SPOs enabled the generation of $\mathrm{H}-\mathrm{Pd}$ " species as well as subsequent hydrolysis of the generated organopalladium species resulting from the hydrogen-transfer step to the acceptor. Unlike most reported aerobic Pd- and Ru-catalyzed reactions, this method was found to be compatible with a wide range of functional groups, including amines, sulfones,

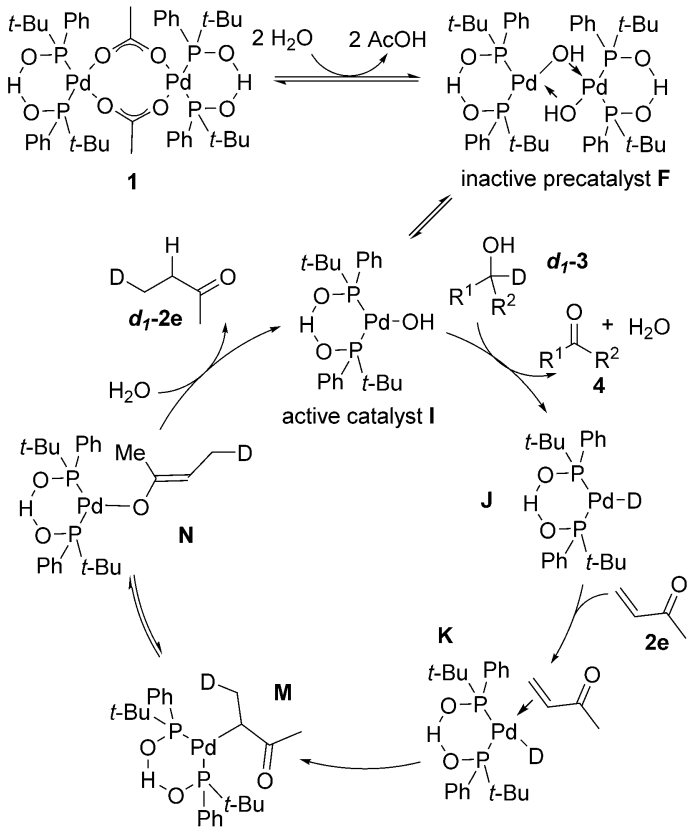

Scheme 5. Proposed mechanistic cycle.

and water- or air-sensitive ones, such as nitriles and sulfides. The catalytic system described herein operated chemoselectively under neutral conditions and left primary aliphatic alcohols intact. Studies of the in situ generated $\mathrm{H}-\mathrm{Pd}$ species for $\mathrm{C}-\mathrm{C}$ bond formation are currently underway. 


\section{Acknowledgements}

We thank the Centre National de la Recherche Scientifique (CNRS) and Ministère de l'Enseignement supérieur et de la Recherche (MESR) for financial support. Dr. S. Chevallier is also gratefully acknowledged for ESI-MS infusion.

[1] J.-E. Bäckvall, Modern oxidation methods, 2nd ed., Wiley-VCH, Weinheim, 2010.

[2] M. S. Sigman, M. J. Schultz, Org. Biomol. Chem. 2004, 2, 2551-2554.

[3] a) K. M. Gligorich, M. S. Sigman, Chem. Commun. 2009, 3854-3867; b) S. S. Stahl, Angew. Chem. Int. Ed. 2004, 43, 3400-3420; Angew. Chem. 2004, 116, 3480-3501; c) J. Muzart, Tetrahedron 2003, 59, 5789-5816.

[4] a) D. C. Ebner, R. M. Trend, C. Genet, M. J. McGrath, P. O'Brien, B. M. Stoltz, Angew. Chem. Int. Ed. 2008, 47, 6367-6370; Angew. Chem. 2008, 120, 6467-6470; b) M. S. Sigman, D. R. Jensen, Acc. Chem. Res. 2006, 39, 221-229； c) D. R. Jensen, M. J. Schultz, J. A. Mueller, M. S. Sigman, Angew. Chem. Int. Ed. 2003, 42, 3810-3813; Angew. Chem. 2003, 115, $3940-3943$.

[5] J. Muzart, Chem. Asian J. 2006, 1, 508-515.

[6] A. J. Ingram, K. L. Walker, R. N. Zare, R. M. Wayrouth, J. Am. Chem. Soc. 2015, 137, $13632-13646$.

[7] D. Wang, D. Astruc, Chem. Rev. 2015, 115, 6621-6686.

[8] J. Muzart, Eur. J. Org. Chem. 2015, 5693-5707.

[9] a) B. Ding, Z. Zhang, Y. Liu, M. Sugiya, T. Imamoto, W. Zhang, Org. Lett. 2013, 15, 3690-3693; b) T. Xu, S. Qiu, G. Li, J. Organomet. Chem. 2011, 696, 46-49; c) Y. Iwai, K. M. Gligorich, M. S. Sigman, Angew. Chem. Int. Ed. 2008, 47, 3219-3222; Angew. Chem. 2008, 120, 3263-3266; d) Y Tsuchiya, Y. Hamashima, M. Sodeoka, Org. Lett. 2006, 8, $4851-4854$.

[10] K. Ren, B. Hu, M. Zhao, Y. Tu, X. Xie, Z. Zhang, J. Org. Chem. 2014, 79, 2170-2177, and references therein.

[11] G. Mann, Q. Shelby, A. H. Roy, J. F. Hartwig, Organometallics 2003, 22, $2775-2789$.

[12] For instance, see: A. Vasseur, C. Laugel, D. Harakat, J. Muzart, J. Le Bras, Eur. J. Org. Chem. 2015, 944-948.

[13] C. Gunanathan, D. Milstein, Chem. Rev. 2014, 114, 12024-12087.

[14] a) T. M. Shaikh, C.-M. Weng, F.-E. Hong, Coord. Chem. Rev. 2012, 256 771-803; b) L. Ackermann, Isr. J. Chem. 2010, 50, 652-663; c) L. Ackermann, Synthesis 2006, 1557-1571; d) L. Ackermann, R. Born, J. H. Spatz, A. Althammer, C. J. Gschrei, Pure Appl. Chem. 2006, 78, 209-214.

[15] L. Ackermann, R. Vicente, N. Hoffmann, Org. Lett. 2009, 11, 4274-4276.

[16] a) R. Lerebours, C. Wolf, Org. Lett. 2007, 9, 2737-2740; b) C. Wolf, R. Lerebours, Org. Lett. 2004, 6, 1147-1150.
[17] D. Martin, D. Moraleda, T. Achard, L. Giordano, G. Buono, Chem. Eur. J. 2011, 17, 12729-12740

[18] a) L. Ackermann, H. K. Potukuchi, A.. Kapdi, C. Schulke, Chem. Eur. J. 2010, 16, 3300-3303; b) L.-Y. Jung, S.-H. Tsai, F.-E. Hong, Organometallics 2009, 28,6044-6053; c) J. Bigeault, L. Giordano, G. Buono, Angew. Chem. Int. Ed. 2005, 44, 4753-4757; Angew. Chem. 2005, 117, $4831-$ 4835.

[19] I. D. Hills, G. C. Fu, J. Am. Chem. Soc. 2004, 126, 13178-13179.

[20] D. Gatineau, D. Moraleda, J.-V. Naubron, T. Bürgi, L. Giordano, G. Buono, Tetrahedron: Asymmetry 2009, 20, 1912-1917.

[21] C. Amatore, A. Jutand, G. Meyer, I. Carelli, I. Chiarotto, Eur. J. Inorg. Chem. 2000, 1855-1859.

[22] C. Amatore, E. Carré, A. Justand, M. A. M'Barki, G. Meyer, Organometallics 1995, 14, 5605-5614.

[23] M. M. Konnick, B. A. Gandhi, I. A. Guzei, S. S. Stahl, Angew. Chem. Int. Ed. 2006, 45, 2904-2907; Angew. Chem. 2006, 118, 2970-2973.

[24] T. Ghaffar, A. W. Parkins, Tetrahedron Lett. 1995, 36, 8657-8660.

[25] a) G.-J. ten Brink, I. W. C. E. Arends, R. A. Sheldon, Adv. Synth. Catal. 2002, 344, 355-369; b) I. W. C. E. Arends, G.-J. ten Brink, R. A. Sheldon, J. Mol. Catal. A 2006, 251, 246-254.

[26] T. J. Wallace, J. E. Hoffmann, A. Schriesheim, J. Am. Chem. Soc. 1963, 85, $2739-2743$.

[27] D. Srimani, G. Leitus, Y. Ben-David, D. Milstein, Angew. Chem. Int. Ed. 2014, 53, 11092-11095; Angew. Chem. 2014, 126, 11272- 11275.

[28] a) R. B. Bedford, J. G. Bowen, R. B. Davidson, M. F. Haddow, A. E. Seymour-Julen, H. A. Sparkes, R. L. Webster, Angew. Chem. Int. Ed. 2015, 54, 6591-6594; Angew. Chem. 2015, 127, 6691-6694.

[29] a) A. Fujii, E. Hagiwara, M. Sodeoka, J. Am. Chem. Soc. 1999, 121, $5450-$ 5458; b) A. E. Sheshenev, A. M. R. Smith, K. K. Hii (Mimi), Nat. Protoc. 2012, 7, $1765-1773$.

[30] G. R. Fulmer, R. P. Muller, R. A. Kemp, K. I. Goldberg, J. Am. Chem. Soc. 2009, 131, 1346-1347.

[31] Z. Wang, Z. Zhang, X. Lu, Organometallics 2000, 19, $775-780$.

[32] S. Cacchi, Pure Appl. Chem. 1990, 62, 713-722.

[33] T. Nishikata, Y. Yamamoto, N. Miyaura, Organometallics 2004, 23, 4317 4324.

[34] Although a hydroxy $\mathrm{Pd}(\mathrm{II})$-alcohol intermediate is seldom reported, it cannot be precluded: see reference [3c].

[35] T. Privalov, C. Linde, K.; Zatterberg, C. Moberg, Organometallics 2005, 24, 885-893; Zatterberg, C. Moberg, Organometallics 2005, 24, 885893. 